Vận dụng kỹ năng phân tích: bàn vui về ông Bụt và thần Đèn

Cộng đồng Business Analyst Việt Nam

30 May 2010

l CÔNGG ĐỒNG BUSINESS ANALYST VIÊTT NAM

BUSINESS SYSTEMS ANALYYT, SYSTEMS ANALYYT, PROCESS ANALYYT, CONSSUTANT, PROJ]ET MANAGER, PRODUCT OWNER

http://www.vinabac.com/node/ 6 


\section{Vận dụng kỹ năng phân tích: bàn vui về ông Bụt và thần Đèn}

tat1409

CN, 30/05/2010 - 21:24

$\underline{\# 1}$

Offline

Truy cập lần cuối: 1 tuần 1 ngày trước

Tham gia: 16/05/2015 - 15:44

Vận dụng kỹ năng phân tích: bàn vui về ông Bụt và thần Đèn

Bàn về vai trò của yếu tố văn hoá và giá trị của phương pháp trong phát triển doanh nghiệp sẽ là chuyện "nói mãi không hết." Dẫu vậy, xu hướng vận động tích cực của nhẩn sinh quan và phương thức làm giàu hướng tới văn minh và công bằng đang thể hiện ngày một rõ nét trong đời sống.

Có yếu tố tưởng chừng như nhỏ nhặt và mơ hồ nhưng tác động liên tục và lâu dài lại có thể tạo ra ảnh hưởng lớn tới cách nhìn nhận cuộc sống, rồi từ đó thể hiện qua hành vi học tập, làm việc, kinh doanh, giao tiếp xã hội... của mỗi người. Kết luận cuối cùng còn phải đợi các nhà nghiên cứu văn hoá-xã hội học. Ở đây lăng kính phân tích được vận dụng để có một cách nhìn thú vị về hai nhân vật quen thuộc trong thế giới cổ tích: ông Bụt và thần Đèn. Gần như có thể đoan chắc những ai mê truyện cổ tích đều quen thuộc và yêu mến hai nhân vật này. Niềm tin vào các giá trị và giải pháp của chuyện cổ tích có quan hệ tới hành xử kinh doanh không?

Trong các câu chuyện cổ tích, thỉnh thoảng lại xuất hiện ông Bụt vào những lúc nhân vật chính tuyệt vọng, hay ở tình thế khốn quẫn nhất. Sau khi lắng nghe và "luôn luôn thấu hiểu" sự tình, ông Bụt sẽ cho một lời khuyên, hoặc chỉ cho một mẹo mực thần kỳ. Vậy là mọi vấn đề sẽ được giải quyết. Thật tuyệt vời! Lắm khi đang lúc làm ăn khó khăn, nhiều sự trắc trở, đầu óc mộng mị vô thường, lại thầm mong có Bụt hiện ra. Câu trả lời cho câu hỏi "Vì sao con khóc?" thường thì là "Bụt ơi, con xin ít vốn..." Là ước vậy thôi, chứ cũng biết chả bao giờ có chuyện ấy.

Ông Bụt hiện ra như một "ngài cố vấn," cùng với kế sách diệu kỳ. Và nhân vật trong chuyện ngay sau đó sẽ làm chính xác những lời Bụt dặn, không bao giờ chần chừ hay hoài nghi. Điều gì xảy nếu câu thần chú của Bụt không có hiệu lực? Câu hỏi này thật khó trả lời. Quyết 
định vâng lời Bụt hoàn toàn do trực giác. Không thể rõ Bụt là ai, xuất thân thế nào, tất cả chỉ là hình ảnh một ông lão phúc hậu, râu tóc bạc phơ, tay chống gậy. Vậy là đủ tin tưởng? Gặp được Bụt cũng rất không chắc chắn. Ngoài cách khóc lóc thảm thiêt và chờ đợi thì không thấy còn cách nào khác gặp Bụt cả. Nhưng Bụt rất tài và chỉ giúp người tốt thôi.

Nhân vật thứ hai cũng nổi tiếng tài giỏi và hay giúp đỡ người khó khăn là thần Đèn. Cách thức làm việc của thần Đèn không giống Bụt. Giải pháp thần Đèn đưa ra sẽ do chính thần Đèn thực hiện. Có lẽ do lường trước sẽ phải thực hiện nhiều nhiệm vụ "vất vả" nên thần Đèn xuất hiện là một gã khổng lồ, vạm vỡ, đầy sinh lực. Thần Đèn có thành tích quá khứ được ghi nhận (do cậy tài năng nên phạm lỗi và bị nhốt trong đèn). Thần Đèn luôn xuất hiện ngay khi cần sự giúp đỡ bằng cách cọ xát cây đèn. Để được thần Đèn phục vụ, phải là chủ nhân của đèn thần và có công giải phóng cho thần Đèn. Đây cũng là điều nguy hiểm, ai có cây đèn thần sẽ ngay lập tức có quyền ra lệnh cho thần Đèn đầy tài phép.

Nếu có thể bạn ước mình được Bụt "cố vấn" hay thần Đèn "phục vụ?"

Trang 525 sách "Văn Minh Làm Giàu \& Nguồn Gốc Của

Cải"

Nguồn saga.vn 


\section{Tài liệu tham khảo:}

[1] Cộng đồng Business Analyst Việt Nam. (2010). Vận dụng kỹ năng phân tích: bàn vui về ông Bụt và thần Đèn. Kỹ năng phân tích. http://www.vinabac.com/node/6

[2] Vương Quân Hoàng. (2007). Văn minh làm giàu \& Nguồn gốc của cải. Nxb Chính trị Quốc gia, Hà Nội. 